\title{
Forming foreign communicative competence by means of the didactic business game
}

\author{
T. A. Gannichenko, K. V. Tishechkina* \\ Mykolayiv National Agrarian University, Mykolayiv, Ukraine \\ *Corresponding author. E-mail: tishechkinakateryna@gmail.com
}

Paper received 27.04.19; Accepted for publication 10.05.19.

\section{https://doi.org/10.31174/SEND-PP2019-197VII79-05}

\begin{abstract}
The article deals with the issues of forming foreign communicative competence as a component of professional competence by means of didactic game. It is considered as an interactive method of learning of foreign language for specific purposes; as an element of acquisition of key competencies by future specialist according to current needs and requirements. The object of this paper is to present theoretical and methodological foundations and practical aspects of the use of didactic games, to give proposals for further improvement of its use in the practice of English teaching for specific purposes. The article reviews the basic principles of didactic games, the possibility of their use in the process of learning English. The authors deal firstly with the problem of the classification of didactic games and determine the didactic structure of business game and analyze the effectiveness of the use of business games in foreign language classes at Mykolayiv National Agrarian University. The theoretical, diagnostic and statistical methods were used for the purposes of this study. Results of the research demonstrate the positive shifts in students' communicative competence levels after use of business games in English learning. Considering a sufficient amount of investigations in this area, the authors concluded that the formation of foreign professional communicative competence with the help of didactic games for future agrarians needs further development. Finally, the authors admit that the use of the game for educational purposes is a promising area of teaching a foreign language.
\end{abstract}

Keywords: foreign communicative competence, communication, didactic game, business simulation (game), role play (game).

Introduction. European integration processes, the need for free access to information, socio-economic and political factors place new educational demands on Ukrainian society for the successful professional integration of the individual as well as for raising social standards. The fluent knowledge of a foreign language (at first, English) as the most common means of distributing knowledge, information, and experience is gaining considerable importance. Formation of foreign communicative competence as a component of professional competence is one of the priority directions in the implementation of the country's development strategy. The process of linguistic education reforming is aimed at the innovation of methods and techniques of specialists training in various sectors of the national economy which are able to compete in the world labor market.

Thus, the choice of the subject matter of this article is due to the need to study the methods of teaching English in order to improve pedagogical methods, tools and techniques, modernization in the general system of linguistic education, and on this basis, the need to identify and disseminate positive experiences in applying effective methods of teaching in a higher educational institution, specifically through didactic games. The relevance of the research is due to the need to study the use of didactic games as an interactive tool for teaching by language for special purposes, as an element of project creation and the future specialist's acquisition of the key competencies in accordance with current demands.

Overview of publications on the topic. The study of the didactic game as a means of formation of foreign communicative competence is researched by Artemieva, Kulish, Semenog, Ternavska, Yelagina, Fedchishin, Kolomiets, Konoplenko, Chubar, Tkachova, Tur; effectiveness of didactic business games as an e-learning method in management trainings was reviewed by Ana Beatriz Hernández-Lara, Enric Serradell-Lopez, Àngels FitóBertran; business games as simulation of the business processes of startups were considered by Willy C. Kriz \&
Eberhard Auchter; stating significant and positive students' attitude and intention toward entrepreneurial activities using business simulation game was proven by Salman Zulfiqar, Binesh Sarwar; simulation and gaming in the network society was observed by Toshiyuki Kaneda \& Hidehiko Kanegae and others.

The purpose of this study is to consider the didactic business game as a teaching method, which provides the formation of professional foreign communicative competence. Analysis of theoretical studies, the generalization of positive experience in foreign language teaching allowed the authors to suppose: business game leads to increasing students professional communicative competence; business game increases motivation to study.

Materials and methods. Having analyzed the studies of famous scientists (Bachman, Baidenko, Canale, Hymes, Khutorskoy, Omaggio, Savignon, Symonenko, Van Ek, Zimniaya, etc.) we determined the communicative competence as a complex intellectual and psychological formation of personality characterized by the ability of a person to communicate effectively in various spheres of life, knowledge of speech and linguistic norms, speaking etiquette, cultural characteristics, social experience and the ability to use this knowledge in accordance with communicative situation [2]. Didactic business games are used to form foreign communicative competence, as they eliminate the contradiction between students' studying and their future professional activities.

Training by action is the most comprehensive and effective teaching method. Participation in didactic games gives students the opportunity not only to study but also to experience the conditions that they can expect after graduation. Acquiring general knowledge is associated with the development of skills and techniques of professional activity. Artemieva notes, that in an effective learning environment, a student does not receive a ready-to-use skill, but obtains an additional one, unknown to him. This promotes the "development" of his professional subjects 
at the level of heuristic tasks and their corresponding teaching methods [1].

The opinion of Tyukov is appropriate for us: "in the educational process, the game is a means of formation and expansion of professional guidance and training in simulated conditions" [4, p. 50]. In addition, it is an effective method of interactive learning; because of the methods of learning are organized methods of interrelated activities of teachers and students, aimed at solving educational tasks of advanced education. Thus, our study identified the didactic game as a means and a method of interactive learning, which contributes to the formation of communicative competence of future specialists.

The use of didactic games is based on the understanding of the game as a human activity, the subject of which is the simulation of other activities. In research literature the division of didactic games into two types is widespread: business simulation game / business game (simulated, innovative, organizational, organizational and mental, managerial, recreational, educational and pedagogical) and role-play / role-playing game (situational and thematic, etc.). Most methodologists see the difference in the fact that in role-playing games a personal interaction is being played, and the business game is being played by a situation that is close to real professional activity. Simulated actions of work generate business game and the simulated actions of communication create the roleplaying game, etc.

Analyzing diversity of didactic game classifications, we came to the conclusion that the communicative didactic game is a role-playing game which is simulating different aspects of life, including the professional sphere, which in this case is called, "business simulation game / business game". So, the business game is a kind of didactic role-playing game. In English learning in a very elementary stage, role-playing games are being used (where different situations of social and domestic content are played), and on the advanced level, the didactic business games (as a kind of role-playing games) take their place. As the learning of English for future agrarian is now an integral part of the professional training of a specialist and is part of his professional competence, the use of business games as a means of professional communication is necessary.

The literature review on this issue allows us to try to define the term "business game". Business game is considered as a form of simulation of the content area and social content of the professional activity, a simulation of relationships, which are illustrative for this type of practical activity.

New knowledge conforms to future professional activities, the training acquires group collective character, and the development of the specialist's personality is carried out as a result of the connection of two types of norms: norms of competent subject actions and norms of social relationships in a team. In such contextual training, meeting didactic and educational goals are combined in one stream of social activity, which is realized in the form of gaming activity. In the process of the game, students are transformed from passive listeners to active participants of the learning process. Because the game has a high level of motivation, it helps to identify their individuality, initiative, creates a relaxed atmosphere and conditions for creativity, and students can simulate the game situation themselves then apply it later on in their own professional activity.

A business game is a complex of situations of professional communication which are united by a single scenario, the form of organization, learning, and control of collective learning activities.

Having considered the didactic game we can note that the didactic business game is a model of group interaction in solving a communicative problem based on an imaginary situation and action that develops spontaneously; it has great opportunities in the formation of communicative competence, namely: 1) it has significant motivational and incentive opportunities; 2) it creates conditions for the appearance of natural communication, creative and logical thinking, and speech skills since it is the most accurate model of communication; 3) it promotes the development of communicative abilities and skills as the necessary factors of the future specialist's communicative competence; 4) it has an ideological value; 5) it is characterized by a large potential usage since it is a multifunctional phenomenon.

For the purpose of our study we used theoretical methods with the intention of determining the theoretical foundations of the problem under study; diagnostic (tests) in order to verify the effectiveness of the didactic game (business game) use for English learning and its impact on the formation of the communicative competence of students; statistical (processing experimental data obtained during the study).

This study surveyed 402 second-year students of Mykolayiv National Agrarian University mostly in the Management Department. We checked out the algorithm of conducting the business game, its purpose, and the main tasks. We have noticed that lessons using business games demonstrate more effective than those using traditional teaching methods.

In studying the use of the business game, we took into account the following: enhancement the interest of students to the study of a foreign language; creation of positive motivation in education; stimulation of intellectual activity; development of higher mental functions; increase focus on communication during lessons and involvement of students into activities; provision of an opportunity for self-realization of each student and the creation of conditions for each student's development and selfimprovement. Since our intention was to share the experience of use business game that helps to form foreign communicative competence, as a sample we considered the business game "The Executive Board meeting". This game simulates a business context in which the teams of players develop their communicative and managerial skills and abilities. Data from students, users of this game, were collected to answer the research questions.

\section{Business game “The Executive Board meeting”}

The purpose of the game is to determine the level of the formation of professional communicative competence. The game task: 1) to form skills of verbal performance; 2) to develop creative autonomy and initiative on the basis of collective activity; 3 ) to develop the ability to use new lexical units and grammatical constructions.

In the proposed business game the following parameters are taken into account: the professional sphere of the 
manager's activity; the level of foreign language proficiency at the time of the game.

Game structure: The first stage is preparatory.

Classroom work: a) an introduction by the teacher, establishing familiarity with the role situation, conflict issues or problems; b) acquaintance with the linguistic content of the game; c) preliminary training on the use of lexical units and grammatical structures. Individual work (at home): a) reading the text, directories, additional material on the proposed problem; b) the selection of information for each individual situation.

At the 1 st preparatory stage, it is advisable to conduct a questionnaire for students in order to identify the degree of orientation in the professional activities and the attitude of students to gaming and creative forms of work. Working out lexical units and speech models will help students to prepare for a business game.

The first task: in subgroups of 4 people the participants should survey each other as to what qualities the future manager (the head of the unit) should have.

The second task: working out the text on the structure of the company and the main functional responsibilities of its specialists. The following questions should be resolved by the students: 1) What structural unit he / she wants to work in and why? 2) What kind of work does he / she want to do and why? 3) What position would he / she like to occupy (leader or subordinate) and why?

The second stage is the game itself.

The following types of games are used: 1) pair game for training in the use of certain lexical units and grammatical structures; 2) games in subgroups (5-6 people) for the formation and development of communicative skills and abilities; 3) group game (discussion, conference, meeting, etc.). Each participant must have a lapel card, which indicates his name and profession (position) in the game, and the conditions and place of the action (the business in the game) have to be established. Role cards are received by all participants of the game. One side of the card should contain information (common to all participants) about the problem to be solved (map, announcement, plan, agenda, etc.), and the reverse side contains the information for each participant in the game (information about character, his or her features, experience, possible line of behavior, etc.). But each participant can show creativity. He has a certain freedom of action and speech in accordance with the situation.

At the second stage, the group assumes the roles of members of the company's Board of Directors, the roles of representatives of the structural subdivisions of the company (divisions) that are subordinated to the main specialists. Each student receives a card stating the name and title of the position. Role cards are issued with an indication of the official duties and agenda of the meeting. The agenda includes: 1) Quarterly report of department heads on the results of financial and economic activity; 2) Approval of the report on financial and economic activity. 3) Perspectives for the company's development for the next quarter. The meeting is held by the president of the company. The main specialists report quarterly results, submit proposals on the prospects for the company's development for the next quarter, improvement of the financial position of the company, etc.

The teacher controls the progress of the game within the concepts of "control - creativity" without taking part in the game or playing a secondary role. In both cases, the teacher watches the players and notes mistakes but does not stop the game for their correction. Fear of making a mistake prevents easy communication, and thus correcting mistakes during the game is unwanted. Control: performing memorized dialogues; contextualized drills; cued dialogues; role-playing. Creativity. Improvisation.

The third stage is final. Class work (game analysis): a) discussion of a business game (assessment of the communicative activity of the participants of the game); b) exchange of thoughts on the subject of the game or a similar problem. The teacher first analyzes the course of the game, necessarily notes good moments, and then points to typical player mistakes and proposes exercises to correct these mistakes. The participants of the game (the players) express their thoughts about the game: what they liked and disliked, the results of the game, what was achieved during the game, etc. Individual work (at home) can include performing a specific task (writing related articles, reports, etc.). According to the theme of our game, students were offered to write a perspective plan for the development of the company.

Results and discussion. All statistical analyses were carried out using descriptors of language proficiency developed in English for Specific Purposes [6] National Curriculum for Universities. The descriptors of language proficiency were based on the Common European Framework [5] - Appendixes I-L. We used diagnostic tests before and after our experimental gaming studying in all language activities. We assessed levels of students' knowledge in speaking, listening, reading and writing with the help of Cambridge English Tests.

Table 1 shows changes in levels of students' knowledge before and after experimental studying in control and experimental groups. It demonstrates the positive shifts in students' communicative competence levels and proves our first hypothesis: business game leads to increasing students' professional communicative competence.

Table 1. Levels of students' knowledge before and after experimental studying

\begin{tabular}{|c|c|c|c|c|c|}
\hline \multirow[t]{2}{*}{ № } & \multirow{2}{*}{$\begin{array}{c}\text { Value } \\
\text { (levels) }\end{array}$} & \multicolumn{2}{|c|}{$\mathrm{CG} \%$} & \multicolumn{2}{|c|}{ EG \% } \\
\hline & & before & after & before & after \\
\hline 1 & elementary & $36(17,48)$ & $26(12,62)$ & $38(19,39)$ & $10(5,10)$ \\
\hline 2 & pre-intermediate & $102(49,51)$ & $98(47,57)$ & $98(50,00)$ & $36(18,37)$ \\
\hline 3 & intermediate & $52(25,24)$ & $62(30,10)$ & $46(23,47)$ & $92(46,94)$ \\
\hline 4 & upper-intermediate & $16(7,77)$ & $20(9,71)$ & $14(7,14)$ & $58(29,59)$ \\
\hline & $\Sigma$ & \multicolumn{2}{|c|}{206 persons $(100 \%)$} & \multicolumn{2}{|c|}{196 persons $(100 \%)$} \\
\hline
\end{tabular}

Consequently, the use of this type of game has a positive effect on the quality and pace of learning. The game creates conditions for the active intellectual activity of its participants, stimulates the intellectual activity of stu- 
dents, and teaches them to predict, investigate and verify the correctness of their decisions and hypotheses. Targeted focus on the development of professional thinking of students by means of the foreign language, along with acquisition of emotional and valuable experience and conflict resolution, emotional and appraisal experience of their own activity and self-affirmation makes the business game one of the most effective methods of teaching a foreign language.

Also, we measured the levels of motivation before and after experimental studying in control and experimental groups. We used the questionnaire of "Methodology for research of the learning activity motives by Rean and Yakunina" [3]. Most of the students are focused on getting a quality education that will help them in the future to become highly qualified specialists. Levels of motivation of learning activities in control groups amounted to $86 \%$, and in experimental groups - $94.6 \%$ (compared with $70 \%$ in $\mathrm{KG}$ and 68.6 in $\mathrm{EG}$ ), that is, after the language training course, the language of instruction increased by $\mathrm{KG}$ in $16 \%$, and in the YE - by $26 \%$. Consequently, the use of the didactic game has a positive effect on the motivation of studying activities, and it argues our second hypothesis.

This study highlights that business games are seen as an appropriate method for fostering professional communicative competence in English training courses by the students. Previous research has stated that, despite a large number of studies examining the effectiveness of business games, further empirical research is required (Buil, Catalán \& Martínez). Also, most of the investigations stress on the positive effect of using didactic games in professional knowledge teaching, the formation of foreign communicative competence and enhancing motivation by means of didactic games (Knogler \& Lewalter). Despite the sufficient amount of research of didactic games, most of them are devoted to the development of skills and abilities in management, improvement of competitive position, strategies of individual growth, etc. The formation of foreign professional communicative competence by means of didactic games (business games) of future specialists in the agrarian sector has been developed insignificantly.

Conclusion. The need for a society of qualified professionals and the small number of hours spent on language teaching prompt teachers to use intensive methods and learning tools, one of which is the didactic game. It supposes that the teacher is able to organize an educational and practical activity in the classroom aimed at modeling future professional activities. So such teacher must have special training in game approach and have particular knowledge both in English and disciplines in the specialty. Besides it suggests that more effort needs to be made in order to adapt to new education methodologies more oriented to experiential learning. We think it necessary to further develop business games for various specialties, in particular, an agrarian profile. In addition, it will be useful the introduction of an additional course on gaming for future teachers, as well as the creation of a specific game simulation course for agrarian specialists, which will help to maximize the potential of a business game. This will conduce to the formation of professional competence of a specialist, including all its components.

\section{ЛІТЕРАТУРА}

1. Артемьева О.А. Общепедагогические и лингводидактические основы активизации познавательной деятельности студентов вузов при обучении иностранному языку на основе системы учебно-ролевых игр: Автореф. дис. ... доктора пед. наук / ТГУ - Тамбов, 1999. - 50 с.

2. Ганніченко Т.А. Формування комунікативної компетенції майбутніх економістів засобами дидактичної гри у процесі мовної освіти: дис. канд. пед. наук / Ганніченко Т.А. - Херсон: Херсонський державний університет, 2009. $262 \mathrm{c}$.

3. Реан, А.А. Психология изучения личности: Учебное пособие. / А.А. Реан. - СПБ.: Изд-во Михайлова В.А., 2000. $288 \mathrm{c}$.

4. Тюков А.А. Организационные обучающие игры и моделирование процессов социального развития личности / А.А.Тюков // Игровое моделирование: методология и практика. - Новосибирск: Наука, 1987. - С. 48-61.

5. Common European Framework of Reference for Languages: Learning, Teaching, Assessment. - Strasbourg: Council of Europe (council for Cultural Cooperation), 2018. - 265 p.

6. English for Specific Purposes. National Curriculum for Universities / [Г.С.Бакаєва, О.А.Борисенко, I.І.Зуєнок та ін.]. К: Ленвіт, 2005 - 119 с.

\section{REFERENCES}

1. Artemieva O. General pedagogical and linguodidactic bases of activization of cognitive activity of university students in teaching a foreign language on the basis of a system of educational role-playing games: Extended abstract of $\mathrm{PhD}$ thesis / TSU - Tambov, 1999. - 50 p.

2. Gannichenko T.A. Formation of communicative competence of future economists by means of didactic game in the process of language education: Extended abstract of $\mathrm{PhD}$ the-

sis / Gannichenko T.A. - Kherson: Kherson State University, 2009. - $262 \mathrm{p}$.

3. Rean, A.A. Psychology of the study of personality: Textbook. / A.A. Rean - SPB .: Publishing house Mikhailov VA, 2000. $-288 \mathrm{p}$.

4. Tyukov A.A. Organization altraining games and modeling processes of social development of the person / A.A.Tyukov // Game simulation: methodology and practice. Novosibirsk: Science, 1987. - P. 48-61. 